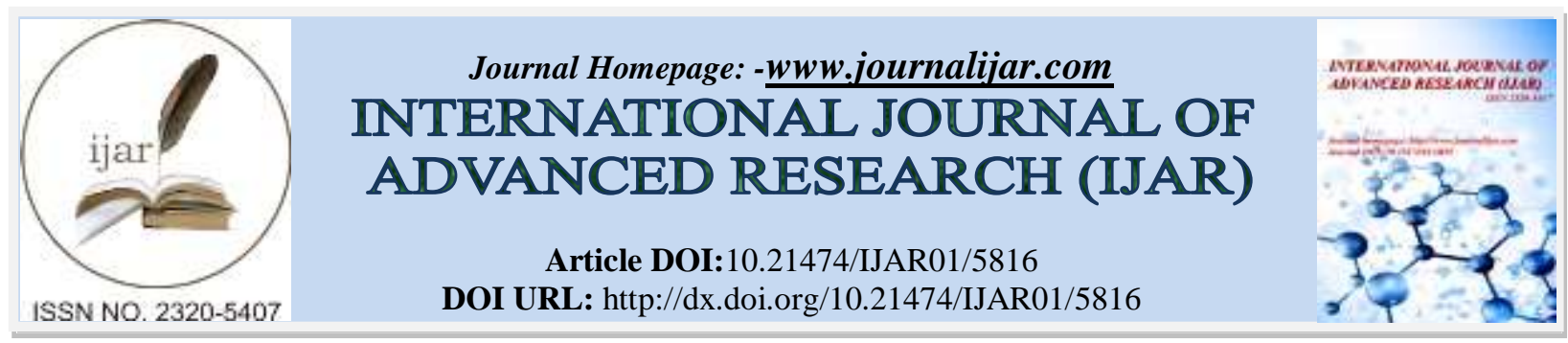

RESEARCH ARTICLE

\title{
OPTIMIZATION MEDIUM OF AMYLASE PRODUCTION BY BACILLUS LICHENIFORMIS STRAIN MGI ORIGINATED FROM PARIANGAN HOT SPRING, WEST SUMATERA, INDONESIA.
}

G.Indriati and RRP.Megahati. Biology Education Department STKIP PGRI Sumbar, Padang, 25137, West Sumatera, Indonesia.

\section{Manuscript Info}

Manuscript History

Received: 09 September 2017

Final Accepted: 11 October 2017

Published: November 2017

Key words:-

Amylase, Bacillus licheniformis,

Pariangan hot spring.

\section{Abstract}

Amylase produced by bacteria or bacteria amylase is an enzyme that can hydrolyze starch to sugar. Amylase is important due to their commercial applications in starch liquefaction, paper, textile fabrics, brewing industry, sugar induction by the production of sugar syrups, pharmaceuticals, and preparing cold water dispersible laundry. Amylase production by Bacillus licheniformis strain MGI that had been isolated from Pariangan hot spring, Tanah Datar district, West Sumatera, Indonesia is still low.The purpose of this study was to increase the production of amylase from Bacillus licheniformis strain MGI.The methods used in this study is to optimize medium of amylase production by Bacillus lichenformis strain MGI such as inoculum size, nitrogen sources, and substrates. Amylase produced by Bacillus licheniformis strain MGI increases with the concentration of inoculum $10 \%$, urea as nitrogen sources, and wheat as a substrate.

Amylases produced by Bacillus licheniformis MGI strains can be used in various industries that use starch as its base material.

Copy Right, IJAR, 201,. All rights reserved.

\section{Introduction:-}

Amylase produced by bacteria or bacteria amylase is an enzyme that can hydrolyze starch to sugar (Megahati et al., 2017). Bacteria amylase is successfully replaced chemical hydrolysis in starch processing industries. Amylase is important due to their commercial applications in starch liquefaction, paper, textile fabrics, brewing industry, sugar induction by the production of sugar syrups, pharmaceuticals, and preparing cold water dispersible laundry (Simair et al., 2017). Amylase is known for its ability to hydrolyze starch into glucose, maltose, a mixture of maltooligosaccharides, and various $\alpha$-limit dextrin-containing $\alpha-1,6$ bonds (Yang and Liu, 2004). Amylase is widely distributed in various species from bacteria to mammals (Suribabu and Helmalatha, 2016).Bacteria have become an important source of amylase for industrial application because they produce amylase with greater thermostability properties as compared to fungal amylase (Malle et al., 2012). The advantages of microbial amylases are low cost, consistency, space, less production time and the modification and optimization process are very easy (Burhan et al., 2003).

Amylase from thermophilic bacteria is resistant to high temperatures that are widely used in the food industry. Amylase is one of the three largest groups of industrial enzymes and accounts for approximately $65 \%$ of the world enzyme (Abdullah et al., 2014). The microorganisms can be tailored to cater to the needs of growing industries and 
to obtain enzymes with desired characteristics like thermostability for example (Sundarram and Mutrhy, 2014). Bacillus licheniformis strain MGI has been successfully isolated from Pariangan hot spring, Tanah Datar district, West Sumatera, Indonesia. Amylase production of Bacillus licheniformis strain MGI is still low because it is a bacteria derived from hot spring (wild-type bacteria). The purpose of this study was to increase the production of amylase from Bacillus licheniformis strain MGI.

\section{Material and Methods:- Inoculum size:-}

Bacillus licheniformis strain MGI originated Pariangan hot spring grown in $50 \mathrm{ml}$ of basal medium pH 8.5 ( $3 \mathrm{~g} / \mathrm{l}$ $\left.\mathrm{KH}_{2} \mathrm{PO}_{4} ; 3 \mathrm{~g} / 1 \mathrm{~g} \mathrm{~K}_{2} \mathrm{HPO}_{4} ; 5 \mathrm{~g} / 1 \mathrm{MgSO}_{4} ; 5 \mathrm{~g} / 1 \mathrm{NaCl} ; 10 \mathrm{~g} / \mathrm{l} \mathrm{starch}\right)$ and incubated for 24 hours at $70^{\circ} \mathrm{C}$. Each inoculum with different concentration $(4,6,8,10$ and $12 \% \mathrm{v} / \mathrm{w})$ moved into a $100 \mathrm{ml}$ new basal medium pH 8.5 and agitated at a speed of $150 \mathrm{rpm}$ for 24 hours at $70^{\circ} \mathrm{C}$. Bacterial cultures were centrifuged at $5,000 \mathrm{rpm}$ and then the supernatant was transferred to a new microcentrifuge tube and assayed for amylase activity.

\section{Nitrogen sources:-}

$1 \%$ source of nitrogen (urea, yeast extract, peptone, beef extract, and tryptone) added to each production medium. Production medium cultured aerobically at a rate of $150 \mathrm{rpm}$ with a temperature of $70^{\circ} \mathrm{C}$ for 24 hours. The inoculum with optimum concentration was transferred into a new production medium and cultured aerobically at $150 \mathrm{rpm}$ with a temperature of $70^{\circ} \mathrm{C}$ for 24 hours. Bacterial cultures were centrifuged at 5,000 rpm for 5 min. The resulting supernatant was transferred into a new microcentrifuge tube for the amylase test.

\section{Substrates:-}

Various substrates (rice, wheat, potatoes, and sago) were added to the production medium and cultured aerobically at $150 \mathrm{rpm}$ with a temperature of $70^{\circ} \mathrm{C}$ for 24 hours. The inoculum with optimum concentration was transferred into a new production medium and cultured aerobicallyat $150 \mathrm{rpm}$ with a temperature of $70^{\circ} \mathrm{C}$ for 24 hours. Bacterial cultures were centrifuged at $5,000 \mathrm{rpm}$ for $5 \mathrm{~min}$. The resulting supernatant was transferred into a new microcentrifuge tube for the amylase test.

\section{Amylase activity:-}

The amylase activity was assayed using a reaction mixture containing $0.5 \mathrm{~mL}$ of $1 \%(\mathrm{w} / \mathrm{v})$ soluble starch as the substrate in potassium phosphate buffer $\mathrm{pH} 7.0$ were incubated at $50^{\circ} \mathrm{C}$ for 5 minutes, add $0.5 \mathrm{ml}$ of amylase and incubated at $50^{\circ} \mathrm{C}$ for 1 hour. The amylase-substrate solution is heated with boiling water for 20 minutes, add 1 ml Samogy-Nelson and heated with boiling water for 20 minutes (Nelson, 1944). The solution was cooled with running water for 1 minute and add $1 \mathrm{ml}$ solution further Arsenomolibdat and measuring absorbance at a wavelength of 540 nm using a spectrophotometer (Visible Genesys).

\section{Result and discussion:-}

Optimization of various parameters and manipulation of media are one of the most important techniques used for the overproduction of enzymes in large quantities to meet industrial demands (Ramesh and Lonsane, 1987).

\section{Inoculum size:-}

The fermentation profile of an organism is usually affected by the initial inoculum size. An increase in inoculum size was found to improve the growth and production of $\alpha$-amylase and reached a maximum of $10 \%$. Increase in inoculum concentration above $10 \%$ was found to decline the amylase production (Figure 1). 


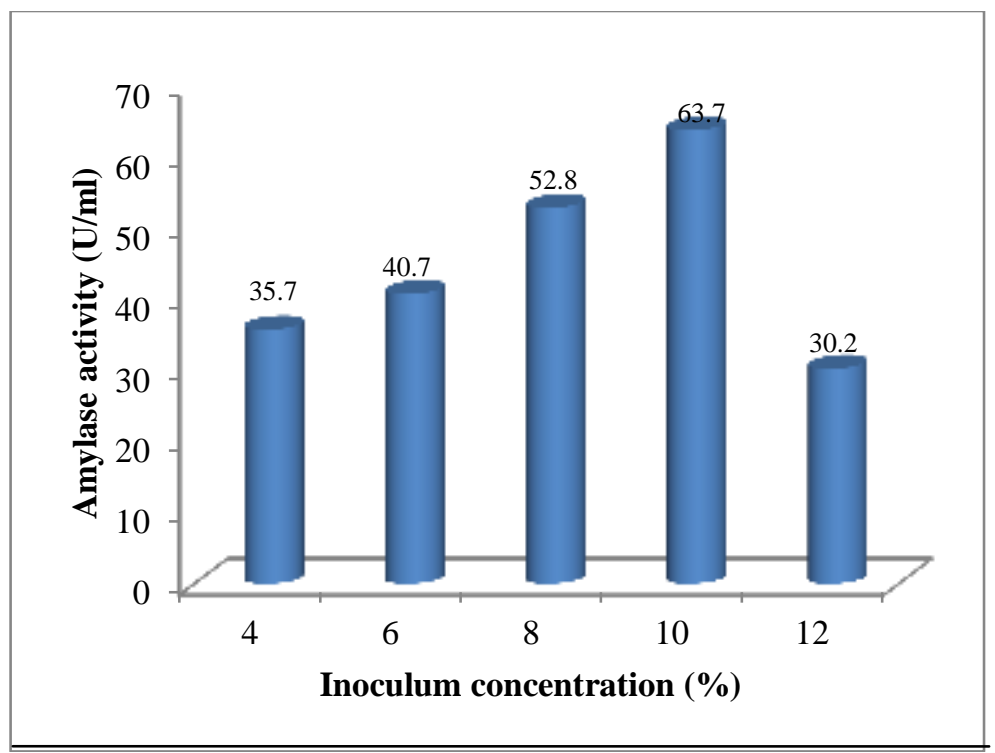

Fig 1:-Effect of inoculum size on amylase production

The same result is also obtained by Simair et al. (2017), 10\% inoculum concentration can increase amylase production. This might be due to a higher size of inoculums resulting in increased competition for carbon source and nutrients, which might lead to exhaustion of nutrients (Kalaiarasi and Parvatham, 2013). Kavipriya and Kousalya, (2017) reported that 1\% inoculum concentration may increase amylase production in Proteus sp. Inoculum size at 2\% might increase amylase activity Brevibacillus borstelensis R1 (Suribabu and Helmalatha, 2016). Inoculum concentration plays a role in increasing the growth and production of amylase in Bacillus licheniformis BT 5.9 (Ibrahim et al., 2013).

\section{Nitrogen sources:-}

All the nitrogen sources used (beef extract, peptone, yeast extract, urea, and tryptone) can increase amylase production, but the use of urea as a source of nitrogen can increase the production of amylase compared to other carbon sources (Figure 2). According to Francois et al. (2013), amylase production is increased by using soybean as a source of nitrogen.

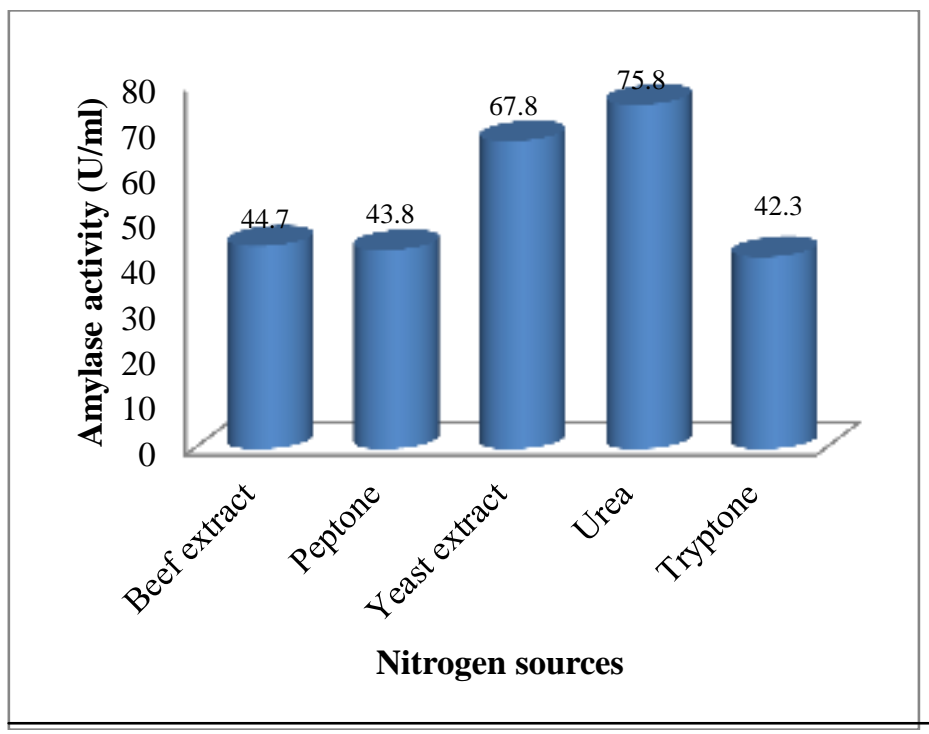

Figure 2:-Effect of nitrogen sources on amylase production

In contrast to Halder et al. (2014), casein is the best source of nitrogen in the production of bacterial amylase.The nitrogen source serves as a second energy source for growth and enzyme secretion (Kumar et al., 2014). Soya bean 
meal was found as the best nitrogen source for $\alpha$-amylase production by Bacillus sp. I-3 (Sodhi et al., 2005). Strains of B. stearothermophilus and B. amylolyticus secreted maximum $\alpha$-amylase in a medium supplemented with $1 \%$ peptone, $0.5 \%$ yeast extract and $0.5 \%$ maltose under vigorous shaking conditions (Dettory et al., 2005).

\section{Substrates:-}

Four substrate types (rice, wheat, potatoes, and sago) are used for bacterial growth optimization and amylase production. The use of rice substrate in the production medium can increase the production of amylase compared to other substrates (Figure 3). Ashraf et al. (2005) reported Bacillus licheniformis GHBB produces the maximum amylase by using wheat as a substrate.

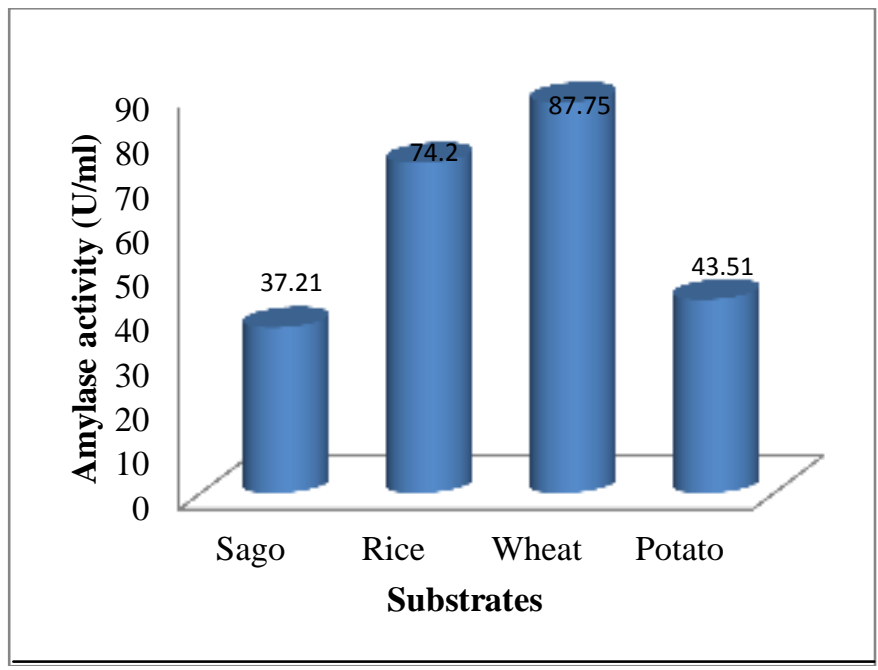

Figure 3:- Effect substrate on amylase production

Amylase from Bacillus licheniformis ATCC 9945a more quickly break down from cereal starch than tuber starch (Bozic et al., 2010). Natural substrates can be used by bacteria as a source of energy to produce amylases and can be obtained at lower prices (Dash et al., 2015). The difference is thought to be influenced by the crystalline form of starch granules. Generally, tubers such as potatoes and cassava have a crystalline structure B while in cereals such as rice and corn have a crystalline structure A. Which crystalline B has a higher water content and a relatively long chain of amylopectin which causes starch is more resistant to enzyme attacks (Puspitasari et al., 2011).

\section{Conclusion:-}

Amylase produced by Bacillus licheniformis strain MGI increases with the concentration of inoculum 10\%, urea as nitrogen sources, and wheat as a substrate. Amylases produced by Bacillus licheniformis MGI strains can be used in various industries that use starch as its base material.

\section{Acknowledgement:-}

The authors thank the Directorate of high education (DIKTI) which has given funding this research.

\section{References:-}

1. Abdullah, JR., Shaheen N, Iqtedar M, Naz S, Iftikhar N. (2014). Optimization of cultural conditions for the production of alpha-amylase by Aspergillus niger (BTM-26) in solid state fermentation. Pakistan Journal of Botany. 46(3):1071-1078

2. Ashraf, HK.,Rana H Zaina, Ul-hag I. (2005). Production of alpha-amylase by a thermophilic strain of Bacillus licheneformis. Journal of Food Technology 3(1):64-67.

3. Bozic, N., Jordi R, Lopez-Santin J, Vujeie Z.(2010). Production and properties of the highly efficient raw starch digesting $\alpha$-amylase from a Bacillus licheniformis ATCC 9945a. Biochemical Engineering Journal.doi: 10.1016/j.bej.2010.10.014

4. Burhan, A., Nisa U, Gokhan C, Omer C, Ashabil A, Osman G. (2003). Enzymatic properties of a novel thermostable, thermophilic, alkaline and chelator resistant amylase from an alkaliphilic Bacillus sp. isolate ANT-6. Process. Biochem. 38: 1397-1403. 
5. Dash BK, Rahman MM, Sarker PK. (2015). Molecular identification of a newly isolated Bacillus subtilis BI19 and optimization of production conditions for enhanced production of extracellular amylase. BioMed Research International 2014:1-9.

6. Dettori, G., Priest FG, Stark JR. (1992). Hydrolysis of starch granules by the amylase from Bacillus stearothermophilus NCA 26.Process Biochem. 27:17-21.

7. Francois, N., Niyonzima, Sunil S, More. (2014). Concomitant production of detergent compatible enzymes by Bacillus flexus XJU-1. Brazilian Journal of Microbiology 45(3): 903-910.

8. Halder, D., Biswas E, Basu M. (2014). Amylase production by Bacillus cereus strain BRSC-S-A26MB. International Journal of Current Microbiology and Applied Sciences 3(6): 1035-1047.

9. Ibrahim, D., Zhu HL, YusofN. (2013).Bacillus licheniformisBT5.9 isolated from Changar hot spring, Malang, Indonesia, as a potential producer of thermostable $\alpha$-amylase. Tropical Life Sciences Research.24 (1):71-84.

10. Kavipriya S and Kousalya P. (2017). Optimization of bacterial inoculum concentration and $\mathrm{pH}$ for the production of amylase and protease using Proteus sp. From sago effluent. International Journal Advanced Research. 5(4):471-474.

11. Kalaiarasi and Parvatham R. (2013). Optimization of process parameters for aamylase production under solidstate fermentation by Bacillus cereus MTCC 10202.African Journal of Microbiology Research. 7(45):51665177.

12. Kumar, SS., Sangeeta R, Soumya S, Ranjan RP, Bidyut B.(2014). Characterizing novel thermophilic amylase producing bacteria from Taptapani Hot Spring, Odishi, India. Jundishapur J Microbiol. 7(12): 1-7

13. Malle, D., Picarima J, Huwae LC, Rahmawati I, Purbowasito W. (2012). Isolation and identification of a thermostable amylase-producing bacterium from Hatuasa hot spring. Microbiology Permi Journal. 6(2):83-88.

14. Megahati, RRP., Mansyurdin, Agustien, A, Tjong DH. (2017). Optimization of bacteria amylase activity from Bacillus licheniformis strain SEM11. Int.J.Curr.Microbiol.App.Sci. 6(11): 2938-2946.

15. Nelson N (1994). A photometric adaptation of the Samogyi method for the determination of glucose. Journal of Biological Chemistry. 153(2):375-380.

16. Puspitasari, F., Nurachman Z, Noer A.S, Radjasa OK, Maarel M, NataliaD.(2011). Characteristics of raw starch degrading amylase from Bacillus aquimaris MKSC 6.2 associated with soft coral Sinularia sp. Starch 63: 461467.

17. Ramesh, MV, Lonsane BK. (1987). A novel bacterial thermostable alpha-amylase system produced by solidstate fermentation. Biotechnol. Lett. 9:501-504.

18. Simair, AA., Lashari S, Qureshi AS, Bhutto AM, Khushk I, Ali CH, Mangrio GS, Lu C. (2017). Production and partial characterization of a $\alpha$-amylase enzyme from Bacillus sp. BCC 01-50 and potential applications. BioMed Research International.

19. Sundarram A and Murthy TPK. (2014). $\alpha$-Amylase production and applications: A review. Journal of applied \& environmental microbiology. 2(14):166-175. 